\title{
Analisis Pengelolaan Dan Pemanfaatan Dana Desa Di Kecamatan Damau Kabupaten Kepulauan Talaud
}

\section{MARIAM MAGDALENA SALINDEHO ${ }^{1}$, LINTJE KALANGI ${ }^{2}$, JESSY D.L. WARONGAN ${ }^{3}$}

\author{
${ }^{1,2,3}$ Program Magister Akutansi, Fakultas Ekonomi dan Bisnis Universitas Sam Ratulangi \\ email: salindehomariam@gmail.com ${ }^{1}$, lintjekalangi@yahoo.com² ${ }^{2}$,jdimarcus@gmail.com
}

\begin{abstract}
This study aims to analyze the Management and Utilization of Village Funds in District Damau Talaud Islands.This is a qualitative exploratory research. Data were obtained by in-depth interviews, observation and documentation study. Key informants were determined by purposive sampling to obtain correct and accurate information. Informants are Village Devices, Village Assistants, Religious Leaders and Customary People. Interviews were conducted by semi-structured in-depth interviews for about 45 to 60 minutes. The triangulation method was used in testing the validity or credibility of data and data sources. Interviews were transcribed into data transcriptions. The results of the interpretation are summarized in the narrative text. The results indicate that the management and utilization of village funds (starting from their planning, executing, administrating and responsibility) are conducted in accordance with Permendagri Number 113 year 2014. This research also found that there are several obstacles in the Management and Utilization of Village Funds in District Damau, for instance the regulations obstruct structure bureaucracy. Those regulations governing the planning process do not match the basic needs of the existing priorities in the village. Other obstacles are limited knowledge and understanding of human resources, ineffective communication between the village head and other village apparatus or between the village head and the community. It is thus the Permendesa must be in accordance with the situation and conditions in the village, so that the planning process can answer the basic needs of the priorities in the village. In addition, guidance and supervision from local government should be more effective including local government should conduct socialization and guide the village treasurer to understand SISKEUDES sufficiently.
\end{abstract}

Keywords: Management of Village Funds, Benefit of Village Funds, Village Fund Issues.

\begin{abstract}
Abstrak. Dalam penelitian ini bertujuan menganalisis Pengelolaan Dan Pemanfaatan Dana Desa Di Kecamatan Damau Kabupaten Kepulauan Talaud. Penelitian ini adalah penelitian kualitatif dengan pendekatan eksploratif. Data diperoleh melalui teknik wawancara mendalam dan studi dokumentasi. Informan kunci ditentukan secara purposive sampling untuk mendapatkan hasil informasi yang tepat dan akurat. Para informan adalah Perangkat Desa, Pendamping Desa dan Tokoh Agama. Wawancara menggunakan In-depth interview jenis semi terstruktur selama 45 hingga 60 menit. Metode triangulasi digunakan dalam pengujian validitas atau kredibilitas data dan sumber data. Hasil interpretasi disimpulkan dalam teks naratif. Hasil penelitian menunjukkan bahwa dalam proses pengelolaan dan pemanfaatan Dana Desa mulai dari perencanaan, pelaksanaan, penatausahaan, pelaporan dan pertanggungjawaban sudah mengacu pada Permendagri Nomor 113 Tahun 2014. Penelitian ini juga menemukan beberapa hambatan dalam pengelolaan dan pemanfaatan dana desa, misalnya regulasi yang menyebabkan hambatan dalam struktur birokrasi. Regulasi yang mengatur pada proses perencanaan tidak sesuai dengan kebutuhan dasar prioritas yang ada di desa. Hambatan lainnya adalah keterbatasan pengetahuan dan pemahaman sumber daya manusia, komunikasi yang tidak efektif antara kepala desa dengan perangkat desa lainnya maupun antara kepala desa dengan masyarakat. Dengan demikian seharusnya regulasi turun sebelum dilaksanakannya musrembang desa sehingga pada saat usulan sampai pada penetapan APBDesa sesuai dengan situasi dan kondisi yang ada di desa supaya proses perencanaan dapat menjawab kebutuhan dasar prioritas di desa. Pembinaan dan pengawasan dari pemerintah daerah juga harus lebih efektif serta pemerintah daerah harus mengadakan sosialisasi dan bimbingan kepada bendahara desa tentang SISKEUDES.
\end{abstract}

Kata Kunci: Pengelolaan Dana Desa, Manfaat Dana Desa, Hambatan Dana Desa.

\section{Pendahuluan}

Nawacita adalah sembilan (9) agenda prioritas dalam Kabinet Kerja Presiden dan Wakil Presiden Joko Widodo dan Jusuf Kalla untuk melanjutkan semangat perjuangan dan cita-cita Ir. Soekarno yang dikenal dengan istilah Triksakti yakni berdaulat secara politik, mandiri dalam ekonomi dan berkepribadian dalam kebudayan. Salah satu agenda prioritas ke-3 Nawacita adalah membangun Indonesia dari pinggiran dengan memperkuat daerah-daerah dan desa-desa dalam kerangka negara kesatuan Republik Indonesia. Nawacita ketiga ini terbukti dengan adanya realisasi dana untuk pembangunan desa melalui Dana Desa yang diatur dalam Undang-Undang Nomor 6 Tahun 2014 tentang Desa.

Tahun 2017 ini adalah tahun ketiga dikucurkannya Dana Desa, dimana anggaran untuk tiap tahun itu meningkat. Pada tahun 2017 ini pemerintah mengalokasikan anggaran Dana Desa sebesar Rp. 60.000.000.000 
meningkat drastis dibanding anggaran Dana Desa tahun 2016 sebesar Rp. 46,9 Triliun. Sesuai dengan amanat UU No 6 Tahun 2014 tentang Dana Desa. Dana ini diharapkan agar dimanfaatkan oleh pemerintah desa untuk membiayai penyelenggaraan pemerintahan, pembangunan dan pemberdayaan masyarakat desa. Dana Desa ini diharapkan mampu mengejar ketertinggalan daerah lain.

Pengelolaan Dana Desa bukanlah hal yang mudah namun memerlukan sistem yang juga harus dibuat secara profesional. Mulai dari segi perencanaan, desa harus membentuk musyawarah desa untuk menetukan belanja bagi Dana Desa pada periode ke depan. Penatausahaannnya pun harus menggunakan sistem yang telah memanfaatkan teknologi informasi. Tidak hanya sistem, Sumber Daya Manusia (SDM) atau perangkat penyelenggara desa pun harus memiliki kapabilitas dalam mengelola dana tersebut. Dengan adanya Dana Desa yang tepat sasaran, tepat jumlah, dan tepat waktu serta dikelola dengan efisien, efektif, dan ekonomis, diharapkan kesejahteraan masyarakat dapat meningkat dengan cepat terutama bagi masyarakat desa dalam peningkatan kesejahteraannya (BPKP, 2017).

Kecamatan Damau adalah salah satu kecamatan di Kabupaten Kepulauan Talaud yang mendapatkan pagu Dana Desa yang cukup besar. Kecamatan Damau terdiri dari 8 (delapan) desa yaitu Desa Ighik, Desa ,Birang, Desa Akas, Desa Akas Balane, Desa Damau Bowone, Desa Damau, Desa Taduwale, dan Desa Peret. Dari survey awal diperoleh bahwa pengelolaan Dana Desa di Kecamatan Damau belum menerapkan prinsip prioritas penggunaan Dana Desa sesuai dengan Peraturan Menteri Desa, Pembangunan Daerah Tertinggal Dan Transmigrasi Nomor 21 Tahun 2015 Tentang Penetapan Prioritas Penggunaan Dana Desa Tahun 2016. Hal ini dibuktikan dengan hasil pelaksanaan di lapangan dimana prioritas pembangunan Dana Desa tidak sesuai dengan RKPDes dan APBDes, karena infrastruktur yang dibangun tidak berdasarkan kebutuhan dasar dari masyarakat. Sebagai contoh dalam musyawarah perencanaan pembangunan desa (musrembang desa) yang dilaksanakan pada bulan Januari tahun 2016 untuk perumusan kebijakan dan program desa tahun anggaran 2016 telah disepakati bersama beberapa program kegiatan yang sesuai dengan kebutuhan dasar masyarakat, namun dalam pelaksanaannya apa yang sudah diprogramkan tersebut tidak dilaksanakan.

Hal ini disebabkan karena adanya keterlambatan regulasi, dimana setelah masyarakat dan pemerintah desa selesai melakukan musrembang desa dan telah menetapkan APBDesa setelah disodorkan ke kabupaten tidak diterima karena tidak sesuai dengan SISKEUDES. Apa yang juga sudah diusulkan oleh masyarakat yang seharusnya sesuai dengan kebutuhan dasar dari desa tapi tidak sesuai dengan Permendesa Nomor 21 Tahun 2015 tentang Penetapan Prioritas Pengelolaan Dana Desa Tahun 2016.

Selain keterlambatan regulasi, berdasarkan profil desa diketahui latar belakang pendidikan aparatur desa sebagian besar berpendidikan Sekolah Menengah Atas (SMA) bahkan ada beberapa diantaranya hanya lulusan Sekolah Menengah Pertama (SMP), dan ada juga yang hanya lulus melalui paket c. Kondisi ini merupakan salah satu masalah yang mendasar yang dihadapi desa dalam hal masih rendahnya kualitas sumber daya manusia (SDM) di desa, termasuk aparatur desa yang memegang kekuasaan administrasi pemerintahan dan pengelolaan Dana Desa. Sehingga masih diragukan kualitas pemahamannya dalam rangka tata kelola administrasi pemerintahan desa yang tertib dan tata kelola keuangan desa yang transparan dan akuntabel yang tertuang dalam pasal 2 (dua) Permendagri Nomor 113 tahun 2014 tentang asas pengelolaan keuangan desa.

\section{Pertanyaan Riset dan Proposisi}

Dasar pemikiran untuk melakukan penelitian tentang Pengelolaan Dana Desa adalah karena topik ini dipandang menarik untuk diteliti. Saat pemerintah mulai mempublikasikan ke masyarakat bahwa tahun 2015 setiap desa akan mendapatkan kucuran dana dari pusat sebesar Rp 1 (satu) milyar guna mendukung pembangunan dan pemeratan ekonomi ditingkat desa, masyarakat menyambutnya dengan gembira, namun tidak sedikit pula yang berpendapat dan beranggapan bahwa anggaran yang direncanakan ini nantinya akan berdampak negatif bagi pengelola keuangan ditingkat desa, mengingat keterbatasan SDM di tingkat desa. Para peneliti mulai melakukan kajian-kajian serta penelitian akan dampak negatif yang bisa saja menghantui program kucuran Dana Desa oleh pemerintah pusat. Mereka juga terdorong untuk memikirkan solusi dan upaya-upaya dini pencegahan/mengantisipasi kemungkinan-kemungkinan yang akan terjadi bila Dana Desa salah sasaran atau diselewengkan. Proposisi : Pertama bila pengelolaan Dana Desa dilaksanakan sesuai dengan Peraturan Menteri Dalam Negeri Nomor 113 Tahun 2014 tentang Pengelolaan Keuangan Desa, maka akan dapat mengatasi berbagai dampak negatif dari pengelolaan Dana Desa itu, terutama program yang tidak tepat sasaran dan penyelewengan dalam pengelolaan Dana Desa. Kedua apabila komunikasi, sumber daya, sikap pelaksana bahkan struktur birokrasi sesuai dengan regulasi yang ada maka akan dapat mengatasi hambatan-hambatan dalam pengelolaan Dana Desa.

\section{Kerangka Konseptual}

Menurut Ibrahim (2015 : 45) kerangka konsep merupakan gambaran atau bagian utuh suatu penelitian, dan merupakan perpaduan dari berbagai aspek, mulai dari permasalahan, aspek-aspek yang terkait yang hendak diteliti, hingga kemungkinan-kemugkinan lain yang ingin dihasilkan dari keseluruhan proses penelitian. Berdasarkan latar belakang masalah, rumusan permasalahan dan teori yang ada, maka kerangka konseptual dalam penelitian ini dapat dilihat dalam gambar berikut. 


\section{Gambar 1 Kerangka Konseptual Penelitian}

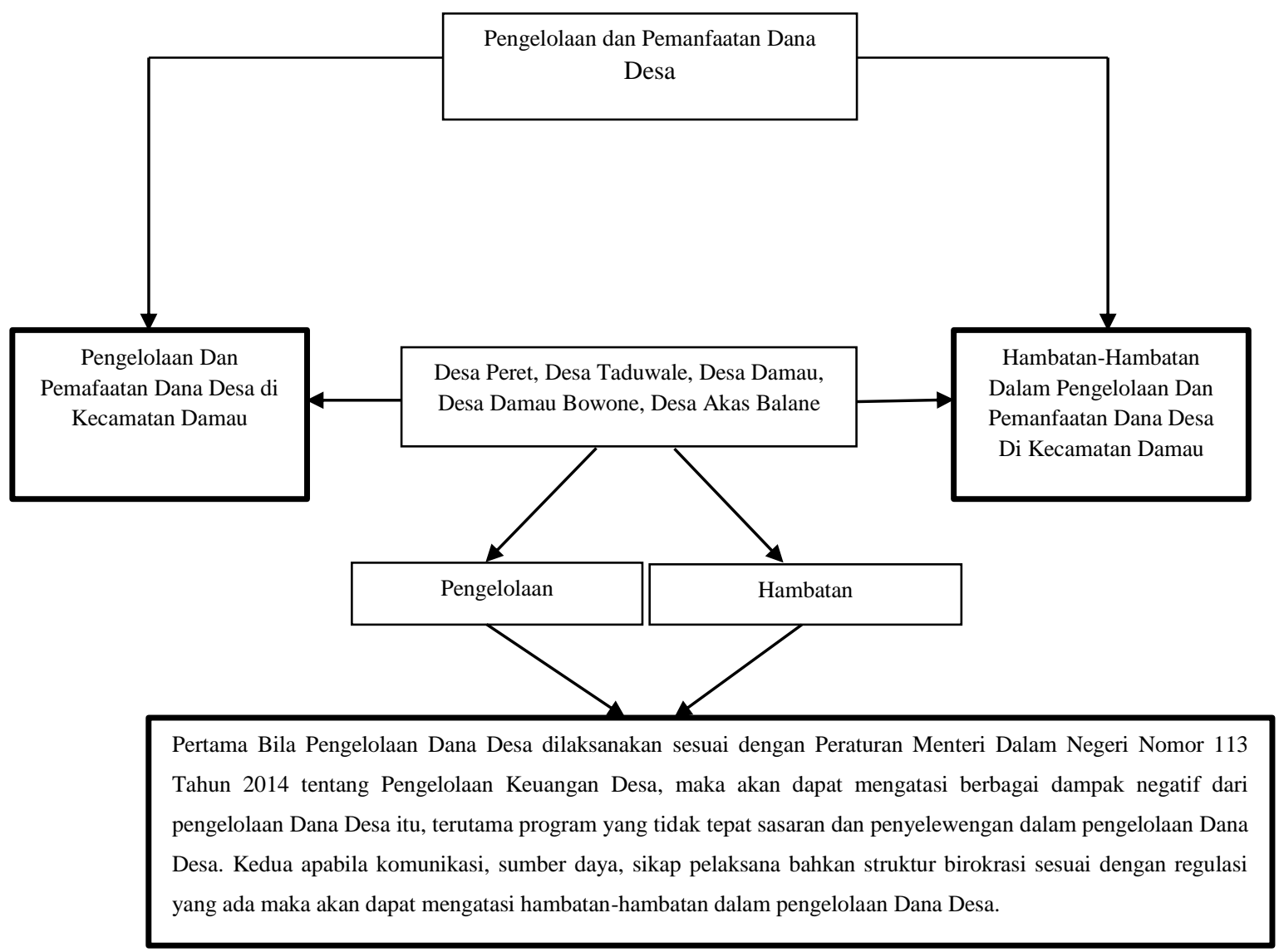

\section{Metode Penelitian}

Penelitian ini menggunakan metode penelitian kualitatif dengan pendekatan eksploratori (exploratory approach.) Metode penelitian kualitatif menurut Sugiyono (2015:1) sering disebut metode penelitian naturalistik karena penelitiannya dilakukan pada kondisi yang alamiah (natural setting). Metode kualitatif ini dipilih agar data yang diperoleh akan lebih lengkap, lebih mendalam, kredibel dan bermakna sehingga tujuan penelitian dapat dicapai. Menurut Arikunto (2010:32) metode eksploratori adalah metode penelitian yang bertujuan untuk menggali suatu informasi. Ibrahim (2015:61) menjelaskan bahwa pendekatan eksploratori dalam penelitian kualitatif adalah cara kerja penelitian yang dimaksudkan untuk menemukan lebih jauh dan mendalam terhadap kemungkinan-kemungkinan lain dari permasalahan yang diteliti. Dengan pendekatan eksploratori, penelitian tidak lagi sekedar menggambarkan atau melukiskan atau menjelaskan seperti apa adanya realitas yang dikaji sebagaimana pada metode deskriptif. Menurut Satori dan Komariah (2013:103) dalam penelitian kualitatif teknik pengumpulan data dapat dilakukan melalui setting dari berbagai sumber, dan berbagai cara. Adapun teknik pengumpulan data yang digunakan dalam penelitian ini adalah sebagai berikut :

a) Wawancara

Susan Stainback dalam Sugiyono (2015:72) mengemukakan bahwa dengan wawancara, maka peneliti akan mengetahui hal-hal yang lebih mendalam tentang partisipan dalam menginterpretasikan situasi dan fenomena yang terjadi, di mana hal ini tidak bisa ditemukan melalui observasi.

Dalam penelitian ini wawancara digunakan untuk menggali hal-hal penting dan menarik untuk diungkapkan dalam penelitian sehubungan dengan Pengelolaan dan Pemanfaatan Dana Desa di Kecamatan Damau yang mengacuh pada Peraturan Menteri Dalam Negeri Nomor 113 Tahun 2014 tentang Pengelolaan Keuangan Desa, untuk pengelolaan Dana Desa sedangkan untuk pemanfaatan Dana Desa mengacuh pada Peraturan Menteri Desa dan Pembangunan Daerah Tertinggal Nomor 21 tahun 2015 tentang Penetapan Prioritas Penggunaan Dana Desa Tahun 2016. Jawaban dari informan tidak dibatasi oleh penulis sesuai dengan pengetahuan dan pemahamannya mengenai pengelolaan dan pemanfaatan Dana Desa. Wawancara dilakukan dengan menggunakan jenis In-depth interviews dengan metode semi terstuktur dengan durasi waktu 30-60 menit dan menggunakan alat perekam tape recorder. 


\section{b) Dokumentasi}

Menurut Ibrahim (2015:93) dokumen atau dokumentasi dalam penelitian mempunyai 2 (dua) makna yang pertama dokumen yang dimaksudkan sebagai alat bukti tentang sesuatu, termasuk catatan-catatan, foto, rekaman video atau apapun yang dihasilkan oleh peneliti. Kedua dokumen yang berkenaan dengan peristiwa atau momen atau kegiatan yang telah lalu, yang padanya mungkin dihasilkan sebuah informasi, fakta dan data yang diinginkan dalam penelitian.

Dokumen dalam penelitian ini adalah menyangkut Peraturan-peraturan, RPJMDes, APBDesa, RKPDes serta dokumen administrasi lainnya. Dokumen-dokumen tersebut antara lain : (1). Dokumen RPJMDes Tahun 2016-2021, (2). Dokumen RKPDesa Tahun 2016, (3). Dokumen APBDes Tahun 2016, (4). Laporan Realisasi APBDes Tahun 2016, (5). Peraturan Bupati Kepulauan Talaud Nomor 2 Tahun 2015.

Adapun dalam penelitian ini, wawancara dilakukan kepada Kepala Desa, Sekretaris Desa, Bendahara Desa, Ketua Badan Permusyawaratan Desa yang terkait dengan pengelolaan Dana Desa, mereka dianggap tepat (key person) untuk berkontribusi dalam penelitian ini. Sedangkan untuk masyarakat yang diwakili tokoh agama, dan pendamping Dana Desa yang berhubungan dengan manfaat dari pengelolaan Dana Desa tersebut. Jumlah informan dalam penelitian ini adalah sebanyak 17 (tujuh belas) orang informan terdiri dari 14 (empat belas) orang informan dari Aparatur Desa, 1 (satu) orang dari tokoh agama serta 2 (dua) orang dari pendamping lokal desa.

\section{Analisis Hasil dan Pembahasan}

Penelitian ini dilaksanakan selama 4 (empat) bulan sejak bulan Mei 2017 hingga bulan September 2017 di Desa Peret, Desa Taduwale, Desa Damau, Desa Damau Bowone dan Desa Akas Balane. Wawancara dilakukan sesuai dengan pedoman wawancara kepada informan kunci yang sudah ditentukan dan digunakan alat perekam untuk merekam seluruh isi wawancara, serta menggunakan instrumen pendukung antara lain buku catatan, alat perekam berupa audio/video, kamera untuk mendokumentasikan kegiatan dilapangan dan laptop untuk mengetik hasil penelitian dan rekaman sehingga berbentuk transkrip wawancara yang kemudian direduksi dan ditentukan tema berdasarkan permasalahan pada bab sebelumnya. Untuk menjawab masalah pertama yaitu : "bagaimana pengelolaan dan pemanfaatan Dana Desa di Kecamatan Damau ditemukan delapan (8) tema yaitu : perencanaan, pelaksanaan, penatausahaan, pelaporan, pertanggungjawaban, pembinaan dan pengawasan, manfaat Dana Desa serta asas pengelolaan Dana Desa yaitu partisipatif dan transparansi. Untuk menjawab masalah kedua yaitu: "hambatan-hambatan apa saja dalam pengelolaan dan pemanfaatan Dana Desa di Kecamatan Damau ditemukan lima (5) tema yaitu: hambatan struktur birokrasi, hambatan sumber daya, hambatan komunikasi, hambatan sikap pelaksana, hambatan letak geografis. Dan hambatan geografis ini dikelompokkan dalam hambatan sumber daya. kemudian didapatkan juga upaya untuk mengatasi hambatan tersebut.

Berdasarkan analisis hasil penelitian yang diperoleh dari wawancara dan dokumentasi selanjutnya dilakukan interpretasi atas temuan yang ada sesuai dengan teori/konsep yang mendukung hasil penelitian. Adapun hasil penelitian dan pembahasan akan diuraikan sebagai berikut. :

\section{Analisis Kesesuaian Pengelolaan Dan Pemanfaatan Dana Desa Di Kecamatan Damau Dengan Peraturan Menteri Dalam Negeri Nomor 113 Tahun 2014.

Sekretaris desa menyusun rancangan APBDesa berdasarkan RKPDesa kemudian disampaikan kepada kepala desa dan selanjutnya disampaikan kepala desa kepada BPD untuk pembahasan selanjutnya pembahasan melalui musyawarah desa untuk menetapkan program prioritas pembangunan yang ada di desa. Untuk perencanaan terdapat kesesuaian tapi untuk jadwal yang seharusnya bulan Oktober tahun berjalan di Kecamatan Damau dilaksanakan pada bulan Januari sampai Februari karena menunggu jadwal dari pemerintah daerah. Begitu juga untuk kegiatan Rancangan APBDesa yang sudah ditetapkan kadang kegiatan yang sudah ada tidak sesuai dengan apa yang ada di SISKEUDES sehingga harus melakukan perubahan kegiatan menyesuaikan dengan apa yang ada di SISKEUDES.

Siagian (2004 : 23-24) menyatakan rencana merupakan suatu keputusan yang diambil sekarang untuk dilaksanakan dalam satu kurun waktu tertentu di masa depan. Teori perencanaan mengatakan bahwa suatu rencana yang baik adalah yang memenuhi berbagai ciri, seperti : 1). Mempermudah usaha pencapaian tujuan 2). Merupakan penjabaran yang sistematik dan strategi dasar organisasi. 3).Dipahami oleh mereka yang akan terlibat dalam pelaksanannya. 4). Komprehensif dalam arti mencakup semua segi kehidupan organisasional. 5). Disusun oleh mereka yang memahami betul hakikat tujuan organisasi. 6). Disusun oleh mereka yang benar-benar memahami teknik perencanaan. 7). Menggambarkan secara jelas apa yang mungkin dan tidak mungkin dicapai. 8). Menunjukkan standar mutu kerja yang dituntut. 9).Terdapat kejelasan kurun waktu yang menjadi cakupannya. 10). Disusun sedemikian rupa sehingga mudah dijabarkan menjadi program kerja.

Berdasarkan teori perencanaan yang sudah dikemukakan oleh Siagian dikaitkan dengan pengelolaan Dana Desa di Kecamatan Damau dapat ditarik kesimpulan bahwa sebenarnya perencanaan sudah sesuai dengan apa yang menjadi kebutuhan dasar masyarakat, karena APBDesa yang sudah disepakati bersama melalui musrembang desa telah disetujui oleh BPD. Namun pada kenyataannya terbentur dengan regulasi yang 
sudah dijabarkan melalui SISKEUDES dimana apa yang sudah diprogramkan tidak termuat dalam SISKEUDES dan ini merupakan salah satu hambatan.

\section{Pelaksanaan}

Pada proses pelaksanaan kegiatan pengelolaan Dana Desa di Kecamatan Damau, kepala desa mengangkat Pelaksana Teknis Kegiatan (PTK) yang pekerjaannya mengawasi dan mengkoordinasi pekerjaan di lapangan. Proses selanjutnya ketika masuk dalam pelaksanaan keuangan maka PTK membuat faktur belanja yang disesuaikan dengan Rencana Anggaran Biaya (RAB). Tim pemeriksa barang yang akan menyatakan barang sesuai dengan nota pesanan atau tidak, barang itu layak atau tidak. Apabila layak maka pelaksana kegiatan membuat Surat Perintah Pembayaran (SPP) dan dimasukan kepada kepala desa sebagai Kuasa Pengguna Anggaran (KPA) yang kemudian kepala desa memberikan disposisi kepada Pelaksana Teknis Pengelolaan Keuangan Desa (PTPKD). Tim pemeriksa barang akan membuat berita acara bahwa barang tersebut adalah benar-benar baik dan sesuai dengan nota pesanan nomor sekian. Kalau sudah dinyatakan sah dan layak dibayar oleh pemeriksa barang maka pelaksana kegiatan mengajukan Surat Perintah Membayar (SPM) kepada kepala desa. Kepala desa sebagai Kuasa Pengguna Anggaran (KPA) akan memberikan disposisi kepada PTPKD supaya boleh menindaklanjuti sehingga prosesnya berjalan baik. Dalam hal ini bendahara hanya bertugas membayar dan menyimpan uang yang sudah dicairkan dari bank, sedangkan sekretaris desa yang mengetahui persis belanja pengeluaran karena sekretaris desa sebagai verifikator.

Berdasarkan teori implementasi kebijakan yang dikemukakan oleh George C. Edward III dalam Tahir (2014) dikaitkan dengan proses pelaksanaan pengelolaan Dana Desa di Kecamatan Damau dapat ditarik kesimpulan bahwa semua proses dalam tahap pelaksanaan ini sudah dilaksanakan berdasarkan Peraturan Menteri Dalam Negeri Nomor 113 Tahun 2014 tentang Pengelolaan Keuangan Desa, walaupun masih terdapat hambatan pada 1 (satu) desa yaitu Desa Damau Bowone dimana untuk proses pelaksanannya tidak mengacu pada regulasi yang ada, dimana kepala desa tidak mengangkat PTPKD sebagai tim pengelola kegiatan bahkan sekretaris desa tidak pernah melakukan verifikasi terhadap dokumen-dokumen yang berhubungan dengan kegiatan yang dilaksanakan.

\section{Penatausahaan}

Pada proses penatausahaan pengelolaan Dana Desa di Kecamatan Damau untuk Desa, Peret, Desa Taduwale dan Desa Damau sudah sesuai dengan Peraturan Menteri Dalam Negeri Nomor 113 tahun 2017 tentang Pengelolaan Keuangan Desa namun ada satu buku yang tidak ada pada bendahara yaitu buku kas pembantu pajak, sedangkan Desa Damau Bowone kepala desa tidak menetapkan PTPKD karena kepala desa sendiri yang melaksanakan penatausahaan. Hal ini terjadi karena kepala desa tidak memiliki komunikasi yang baik dengan sekretaris desa dan perangkat desa lainnya. Sedangkan untuk Desa Akas Balane pada tahun 2016 kepala desa tidak mengangkat PTPKD karena tidak ada anggaran untuk membayar insentif dari tim PTPKD. Dalam organisasi komunikasi mempengaruhi setiap individual yang bekerja untuk organisasi. Komunikasi menjadi penting karena keberhasilan seorang manajer mempengaruhi orang lain dengan atau melalui siapa ia mencapai tujuan organisasional tergantung dari kemampuannya berkomunikasi yaitu menyampaikan ide-ide dan menerima saran-saran. Komunikasi berperan sebagai sarana untuk manajer untuk menyampaikan informasi, seperti halnya suatu kebijakan dan menerima feedback dari pegawai. Komunikasi juga berperan sebagai sarana dalam memadukan aktivitas-aktivitas secara terorganisasi (Silalahi 2015 : 270,272-273).

\section{Pelaporan}

Proses pelaporan pengelolaan Dana Desa di Kecamatan Damau dimana laporannya dimulai dari pelaksana kegiatan berdasarkan kegiatan yang dibuat kemudian lewat bendahara dilakukan penatausahaan bersama tim PTPKD yang dikoordinir oleh sekretaris desa dan bentuk laporan yang sesungguhnya adalah laporan kegiatan yang dimasukan dalam bentuk SPJ. Kemudian laporan Dana Desa tersebut disampaikan kepada ibu Bupati oleh kepala desa melaui bapak camat.

Laporan Dana Desa adalah 2 (dua) semester dimana semester pertama adalah bulan Juli dan semester kedua adalah bulan Januari tahun selanjutnya. Tapi laporan kadang-kadang terlambat dikarenakan Dana Desa masuk di rekening desa terlambat. Misalnya tahun ini Dana Desa masuk bulan Mei maka tidak mungkin laporannya di bulan Juni atau Juli tetapi di bulan September untuk tahap pertama sedangkan untuk tahap kedua adalah di bulan Januari atau Februari berbarengan dengan laporan ahkir tahun. Berdasarkan teori implementasi kebijakan yang dikemukakan oleh George C. Edward III dalam Tahir (2014) dikaitkan dengan proses pelaporan pengelolaan Dana Desa dapat ditarik kesimpulan bahwa laporan terlambat ini dikaitkan dengan struktur birokrasi, ketika regulasi lambat maka proses kegitan yag sudah dijadwalkan tidak dilaksanakan sesuai tepat waktu sehingga pelaporan pun dapat terlambat, karena semua proses dalam pengelolaan Dana Desa diatur melalui regulasi yang ada.

\section{Pertanggungjawaban}

Pada proses pertanggungjawaban ini di mulai dari setiap dana yang keluar dicatat oleh bendahara dikelola oleh PTPKD termasuk sama-sama dengan sekretaris desa selaku koordinator PTPKD untuk membuat laporan. Kemudian disampaikan kepada kepala desa untuk dikaji kebenarannya apa masih ada yang tidak dilaporkan atau masih ada kesalahan-kesalahan karena kepala desa adalah Kuasa Pengguna Anggaran (KPA). Kalau laporan sudah pasti maka akan diteruskan kepada pemerintah daerah yaitu kepada Bupati oleh kepala desa 
karena itu merupakan tugas dari kepala desa. Selanjutnya pertanggungjawaban mengacu pada apa yang sudah dibelanjakan. Pada saat mencairkan tahap kedua maka SPJ tahap pertama harus dimasukan terlebih dahulu. Pertanggungjawaban mulai dari pelaksana kegiatan mulai tanggal 10 bulan berjalan harus melaporkan semua kegiatan kepada kepala desa dan semua pembelanjaan yang dibelanjakan pelaksana kegiatan itu berupa SPJ.

Tata kelola pemerintahan yang baik merupakan salah satu tuntutan masyarakat yang harus dipenuhi. Salah satu pilar tata kelola tersebut adalah akuntabilitas. Akuntabilitas adalah mempertanggungjawabkan pengelolaan sumber daya serta pelaksanaan kebijakan yang dipercayakan kepada entitas pelaporan dalam mencapai tujuan yang telah ditetapkan secara periodik (SAP, 2005). Akuntabilitas mensyaratkan bahwa pengambil keputusan berperilaku sesuai dengan mandat yang diterimanya. Untuk ini, perumusan kebijakan bersama-sama dengan cara dan hasil kebijakan tersebut harus dapat diakses dan dikomunikasikan secara vertikal maupun horizontal dengan baik (Mardiasmo, 2002 : 29). Akuntabilitas adalah kemampuan memberi jawaban kepada otoritas yang lebih tinggi atas tindakan seseorang/sekelompok orang terhadap masyarakat luas dalam suatu organisasi (Rasul, $2002: 8$ ).

\section{Pembinaan Dan Pengawasan}

Pada proses pengelolaan dan pemanfaatan Dana Desa di Kecamatan Damau juga melalui tema yang sudah ditemukan ada tema pembinaan dan pengawasan. Pembinaan dan pengawasan juga sangat dibutuhkan dalam proses pengelolaan karena akan mendorong pelaksana kegiatan untuk bekerja semaksimal mungkin. Pembinaan dan pengawasan ini dimulai dari pengawasan kepala desa kepada pengelola kegiatan, kemudian pengawasan badan Permusyawaratan Desa (BPD) kepada kepala desa dan pengelola kegiatan serta pengawasan dari inspektorat.

Kepala desa bersama dengan lembaga yag ada melakukan pengawasan secara dekat kepada seluruh kegiatan yang dilaksanakan. Kemudian Inspektorat rutin melakukan pengawasan sesuai dengan tahapan pemerintah daerah untuk pemeriksaan. Kalau inspektorat turun satu semester satu kali begitu juga dengan pendamping desa banyak kali. Pembinaan dan pengawasan seharusnya yang memiliki peran penting disini adalah pemerintah daerah dan pemerintah provinsi, karena dalam pasal 44 (empat puluh empat) Peraturan Menteri Dalam Negeri 113 Tahun 2014 tentang Pengelolaan Keuangan Desa menyatakan bahwa ayat (1). Pemerintah provinsi wajib membina dan mengawasi pemberian dan penyaluran Dana Desa, Alokasi Dana Desa (ADD), Bagi Hasil Pajak dan Retribusi Daerah dari Kabupaten/kota kepada desa. Sedangkan ayat (2). menyatakan bahwa pemerintah kabupaten/kota wajib membina dan mengawasi pelaksanaan pengelolaan kuangan desa.

Berdasarkan Peraturan Menteri Dalam Negeri Nomor 113 Tahun 2014 pasal 44 (empat puluh empat) dikaitkan dengan pembinaan dan pengawasan dalam rangka pengelolaan dan pemanfaatan Dana Desa di Kecamatan Damau dapat ditarik kesimpulan bahwa untuk pengawasan dari daerah hanya dilakukan oleh Inspektorat dan untuk pengawasan secara internal dilakukan oleh lembaga yang ada di desa yaitu Badan Permusyawaratan Desa (BPD).

\section{Manfaat Dana Desa}

Pada pelaksanaan pengelolaan Dana Desa tahun 2016 di Kecamatan Damau ada begitu banyak manfaat yang dirasakan oleh masyarakat dengan hadirnya Dana Desa ini, baik manfaat dalam bidang infrastruktur maupun manfaat dalam bidang pemberdayaan. Berdasarkan teori keadilan yang dikemukakan oleh John Stuart Mill dalam Karen (1986) dikaitkan dengan manfaat pengelolaan Dana Desa di Kecamatan Damau dapat disimpulkan bahwa masyarakat Damau sangat merasakan dampak dari adanya Dana Desa ini karena baik pembangunan infrastruktur maupun program pemberdayaan yang dilaksanakan sudah dapat membantu meningkatkan taraf hidup masyarakat bahkan dapat menekan angka urbanisasi. Walapun dalam beberapa program pemberdayaan masih tidak berhasil, karena pemahaman masyarakat yang selalu menganggap bahwa dana tersebut akan tetap diberikan oleh pemerintah.

\section{Asas Pengelolaan Dana Desa}

Asas pengelolaan Dana Desa untuk transparansi di Desa Peret sudah tidak diragukan lagi karena ketika dana masuk ke rekening kas desa dan ketika pelaksanaan kegiatan selesai dilaksanakan maka kepala desa akan membuat laporan pertanggungjawaban serta akan menyampaikan kepada masyarakat secara langsung baik melalui pengeras suara atau melalui kegiatan-kegiatan sosial yang ada di desa. Sedangkan tingkat partisipasi masyarakat sangat tinggi mulai dari proses perencanaan melalui musyawarah desa masyarakat dihadirkan selanjutnya pada proses pelaksanaan kegiatan. Sedangkan untuk Desa Taduwale, Desa Damau dan Desa Akas Balane transparansi pertanggungjawaban kegiatan disampaikan pada saat dilaksanakan musyawarah, hal ini sama pada saat masyarakat menyampaikan aspirasi lewat musyawarah. Hanya Desa Damau Bowone yang tidak sama sekali menyampaikan kepada masyarakat.

Transparansi berasal dari kata dasar transparan yang berarti terbuka/jelas/nyata. Transparansi adalah memberikan informasi keuangan yang terbuka dan jujur kepada masyarakat berdasarkan pertimbangan bahwa masyarakat memiliki hak untuk mengetahui secara terbuka dan menyeluruh atas pertanggungjawaban pemerintah dalam pengelolaan sumber daya yang dipercayakan kepadanya dan ketaatannya pada peraturan perundang- undangan (SAP, 2005). 
Partisipatif menurut Sujarweni (2015) adalah prinsip dimana setiap warga desa mempunyai hak untuk terlibat dalam setiap pengambilan keputusan pada setiap kegiatan yang diselenggarakan oleh pemerintahan desa dimana mereka tinggal. Keterlibatan masyarakat desa dalam rangka pengambilan keputusan tersebut dapat secara langsung dan tidak langsung.

\section{Hambatan-Hambatan Dalam Pengelolaan dan Pemanfaatan Dana Desa Di Kecamatan Damau. Hambatan Struktur Birokrasi}

Hambatan struktur birokrasi dalam pengelolaan Dana Desa di Kecamatan Damau yaitu kegiatan didasarkan pada hak asal usul tapi terhambat dengan regulasi, dalam penentuan prioritas pengelolaan Dana Desa di Kecamatan Damau yang dihasilkan lewat musyawarah desa melalui penggalian gagasan dari dusun, terdapat beberapa program kegiatan yang sangat mendesak terutama di bidang infrastruktur tetapi ketika disesuaikan dengan Peraturan Menteri Desa Pembangunan Daerah Tertinggal Nomor 21 Tahun 2015 tentang Penetapan Prioritas Penggunaan Dana Desa Tahun 2016 tidak sesuai sehingga apa yang menjadi prioritas tidak dilaksanakan. Permendesa ini juga tidak sesuai dengan situasi dan kondisi yang ada di Kecamatan Damau. Dari hasil penelitian juga diperoleh bahwa regulasi sering terlambat sehingga masyarakat sudah melakukan musyawarah terlebih dahulu baru Permendesa muncul sehingga pemerintah desa tidak dapat membuat patokan dalam musyawarah desa karena mengikuti Permendesa.

Implementasi kebijakan yang bersifat kompleks menuntut adanya kerjasama banyak pihak, ketika struktur birokrasi tidak kondusif terhadap implementasi suatu kebijakan maka hal ini akan menyebabkan ketidakefektifan dan menghambat jalannya pelaksanaan kebijakan. Birokrasi merupakan salah satu institusi yang paling sering bahkan secara keseluruhan menjadi pelaksana kegiatan

\section{Hambatan Sumber Daya}

Dalam pengelolaan dan pemanfaatan Dana Desa di Kecamatana Damau ditemukan 3 (tiga) faktor penghambat dalam sumber daya yaitu sumber daya manusia, sarana prasarana dan keadan letak geografis. Sumber daya manusia berkenan dengan kemampuan bendahara yang tidak bisa mengoperasikan leptop bahkan tidak mengerti sistem SISKEUDES sehingga masih diperlukan pelatihan-pelatihan untuk meningkatkan kemampuan dari bendahara dalam melakukan pertanggungjawaban pengelolaan Dana Desa. Silalahi (2015 : 242) menyatakan SDM merupakan elemen penting dan merupakan aset terpenting dari organisasi dibanding dengan elemen lainnya. Manusia dalam organisasi memiliki peran dan fungsi penting bagi terwujudnya tujuan organisasi. Manusia yang membuat sumber-sumber lain dari suatu organisasi bekerja dan membuat organisasi bergerak.

Selanjutnya sumber daya bukan manusia atau sumber daya material adalah berbagai fasilitas sarana prasarana yang dibutuhkan untuk mendukung pencapaian tujuan. Sebab meskipun manusia menjadi elemen penting dan menentukan dalam pencapaian tujuan keorganisasian tetapi jika tidak disertai atau didukung oleh sumber daya material yang memadai, maka tujuan yang sudah ditetapkan tidak akan tercapai secara optimum Silalahi (2015 :261). Hambatan sumber daya kedua adalah sarana prasarana yang tidak memadai misalnya tidak ada jaringan internet yang menyebabkan Kecamatan Damau ini sangat ketinggalan informasi dalam mengakses peraturan atau pun informasi tentang pengelolaan Dana Desa ini. Pemerintah hanya menunggu informasi yang disampaikan oleh pemerintah daerah. Hal ini juga menyebabkan terhambatnya penyampaian informasi kepada masyarakat tentang pengelolaan Dana Desa.

Hambatan yang ketiga yang dikelompokan dalam hambatan sumber daya adalah adalah letak geografis. Kecamatan Damau adalah salah satu kecamatan yang masuk dalam gugusan pulau terluar berdasarkan Keputusan Presiden Nomor 6 Tahun 2017 tentang Penetapan Pulau-Pulau Kecil Terluar, dimana melalui Keputusan Presiden ini menyatakan ada 111 pulau-pulau kecil terluar yang didalamnya Suwesi Utara memiliki 12 pulau terluar antara lain Pulau Bongkil ( Pulau Bangkit), Pulau Mantehage (Pulau Manterawe), Pulau Makalehi, Pulau Kawaluso, Pulau Kawio, Pulau Marore, Pulau Batuwaikang, Pulau Miangas, Pulau Marampit, Pulau Intata, Pulau Kakorotan dan Pulau Kabaruan. Di Pulau Kabaruan ini terdapat 2 (dua) kecamatan yaitu kecamatan Kabaruan dan Kecamatan Damau.

Karena letak geografis ini Kecamatan Damau banyak mengalami keterlambatan dalam informasi mengenai Dana Desa. Letak geografis merupakan salah satu hambatan dalam pengelolaan Dana Desa pada beberapa desa di Kecamatan Damau karena Kecamatan Damau ini pada bulan tertentu cuacanya sangat ekstrim sehingga masyarakat untuk melakukan aktivitasnya ke kota tidak ada. Ini terjadi karena dari kota kabupaten menuju ke kecamatan ini harus menempuh perjalanan dengan menggunakan perahu motor atau speedboat yang merupakan alat transportasi masyarakat setempat dengan waktu kurang lebih 2 (dua) jam. Hal ini juga mengakibatkan biaya (harga) barang meningkat sehingga kadang sulit menyesuaikan dengan apa yang sudah ditetapkan dalam RAB oleh tim PTPKD. 


\section{Hambatan Komunikasi}

Dalam penelitian ini ditemukan hambatan komunikasi yaitu hambatan komunikasi antara kepala desa dengan perangkat dan masyarakat. Dimana ada salah satu kepala kepala melaksanakan pengelolaan Dana Desa mulai dari perencanaan sampai ke pertanggungjawaban hanya dibuat sesuai dengan keinginan kepala desa dan tidak memperhatikan aspirasi dari masyarakat. Silalahi ( 2015 : 274-275) menyatakan komunikasi penting karena fungsinya dalam organisasi. Pegawai menetapkan tujuan-tujuan spesifik , bekerja untuk memenuhi tujuan tersebut dan menerima balikan tentang progres terhadap tujuan-tujuan itu. Untuk komunikasi diperlukan karena dapat berfungsi sebagai : a). Fungsi kontrol. Melalui komunikasi dapat dikontrol perilaku atau kegiatan anggota kelompok dengan cara tertentu; b). Fungsi motivasi. Melalui komunikasi dapat ditingkatkan komunikasi pegawai dengan menjelaskan apa yang harus dikerjakan, seberapa baik yang mereka kerjakan dan apa yang dapat dikerjakan untuk meningkatkan kinerja mereka; c). Fungsi ekspresi emosi. Melalui komunikasi tiap anggota dapat mengungkapkan perasaan mereka, seperti rasa puas atau tidak puas dan pemenuhan sosial kebutuhan mereka; d). Fungsi informasi. Komunikasi menyampaikan informasi dari pimpinan ke bawahan atau sebaliknya. Fungsi ini juga memberi petunjuk, pedoman atau informasi yang diperlukan oleh pimpinan atau bawahan. Komunikasi berfungsi menyampaikan informasi yang berhubungan dengan kepentigan umum dan lingkungan tugas organisasi secara keseluruhan. Komunikasi berfungsi menyampaikan informasi dan pengetahuan terutama yang berhubungan dengan pekerjaan atau pelaksanaan tugas dari seseorang kepada orang lain sehingga pekerjaan dapat dijalankan secara benar dan kerjasama tercipta; e) Fungsi komando. Melalui komunikasi atasan memberi instruksi pelaksanaan tugas-tugas tentang apa yang harus dikerjakan kepada bawahan. Komunikasi mendorong dan mengarahkan pegawai untuk melakukan pekerjaan; f). Fungsi integratif. Melalui komunikasi dapat diintegrasikan pekerjaaan dan unit-unit sehingga antara karyawan dan manajer menunjukkan kepaduan (cohesiveness). Disamping itu komunikasi membantu memelihara hubungan sosial orgaisasional dan membangun kebersamaan orang-orang yang melakukan kerjasama. Faktor komunikasi dalam teori implementasi kebijakan yang dikemukakan oleh George C. Edward III dalam Tahir (2014) menyatakan bahwa komunikasi dapat berjalan secara efektif, maka yang harus bertanggungjawab terhadap implementasi sebuah kebijakan harus mengetahui apa yang harus dilakukannya. Perintah untuk mengimplementasikan kebijakan harus disampaikan secara jelas, akurat dan konsisten kepada orang-orang yang mampu.

\section{Hambatan Sikap Pelaksana}

Hambatan sikap pelaksana yang ditemukan pada penelitian yaitu sikap pimpinan dalam hal ini kepala desa yang sering mengambil keputusan sendiri tanpa mengadakan musyawarah dengan masyarakat atau perangkat desa lainnya. Faktor Sikap Pelaksana menurut George C. Edward III dalam Tahir (2014) merupakan faktor penting ketiga dalam pendekatan mengenai studi implementasi kebijakan publik. Jika implementasi kebijakan diharapkan berlangsung efektif, para pelaksana kebijakan tidak hanya harus mengetahui apa yang harus dilakukan dan memiliki kapabilitas untuk melaksanakannya tetapi mereka juga harus mempunyai keinginan untuk melaksanakan kebijakan tersebut.

\section{Upaya Mengatasi Hambatan Pengelolaan Dana Desa Di Kecamatan Damau. Upaya mengatasi hambatan struktur birokrasi}

Mengatasi hambatan birokrasi ini pemerintah desa berusaha berhubungan terus dengan pemerintah daerah atau berkonsultasi dengan pendamping lokal desa atau pendamping desa untuk mendapatkan solusi terhadap permasalahan yang dihadapi. Dalam pengelolaan Dana Desa sepenuhnya diserahkan kepada desa pengelolaannya yaitu termasuk perencanaan-perencanaan diserahkan kepada desa karena kepentingan yang ada di desa itu yang dapat mengetahui secara pasti adalah masyarakat desa itu sendiri, sehingga tidak menjadi kendala dari apa yang menjadi kebutuhan skala prioritas menjadi kebutuhan terahkir karena tidak dapat direkrut dalam regulasi.

Teori perencanaan menurut Siagian (2004 : 22-24) menyatakan bahwa sebagai salah satu langkah dalam proses administrasi, rencana merupakan rincian suatu strategi sekaligus sebagai langkah utama untuk operasionalisasinya. Rencana merupakan suatu keputusan yang diambil sekarang untuk dilaksanakan dalam satu kurun waktu tertentu di masa depan. Sebagai rincian strategi rencana harus mengandung jawaban yang tepat tentang : a). Apa yang akan dilakukan; b). Di mana berbagai kegiatan akan diselenggarakan; c). Bilamana berbagai kegiatan itu akan dilaksanakan; d). Metode dan teknik kerja apa yang akan digunakan; e). Siapa yang akan melakukan; f). Mengapa semua itu harus dilakukan.

\section{Upaya mengatasi hambatan Sumber Daya}

Mengatasi hambatan sumber daya ini terutama sumber daya manusia, pemerintah desa seharusnya berkoordinasi dengan pemerintah daerah untuk melaksanakan pelatihan tentang pengelolaan keuangan desa dalam rangka meningkatkan profesionalisme dari tim PTPKD terutama bendahara dan sekretaris desa. Silalahi (2015 : 242) menyatakan SDM merupakan elemen penting dan merupakan aset terpenting dari organisasi dibanding dengan elemen lainnya. Manusia dalam organisasi memiliki peran dan fungsi penting bagi terwujudnya tujuan organisasi. Manusia yang membuat sumber-sumber lain dari suatu organisasi bekerja dan membuat organisasi bergerak. 
Yusuf (2015) mendefinisikan Sumber Daya Manusia sebagai individu yang merancang dan memproduksi keluaran dalam rangka pencapaian strategi dan tujuan yang telah ditetapkan oleh organisasi. Tanpa individu yang memiliki keahlian atau kompetensi, maka mustahil bagi organisasi untuk mencapai tujuan. Sumber daya manusia inilah yang membuat sumber daya lainnya dapat berjalan.

\section{Upaya mengatasi hambatan komunikasi}

Mengatasi hambatan komunikasi ini pemerintah desa berusaha membangun komunikasi yang baik melalui musyawarah. Menurut Silalahi ( 2015 : 274-275) menyatakan komunikasi penting karena fungsinya dalam organisasi. Pegawai menetapkan tujuan-tujuan spesifik, bekerja untuk memenuhi tujuan tersebut dan menerima timbal balik tentang progres terhadap tujuan-tujuan itu. Untuk komunikasi diperlukan karena dapat berfungsi sebagai : a). Fungsi kontrol. Melalui komunikasi dapat dikontrol perilaku atau kegiatan anggota kelompok dengan cara tertentu; b). Fungsi motivasi. Melalui komunikasi dapat ditingkatkan komunikasi pegawai dengan menjelaskan apa yang harus dikerjakan, seberapa baik yang mereka kerjakan dan apa yag dapat dikerjakan untuk meningkatkan kinerja mereka. c). Fungsi ekspresi emosi. Melalui komunikasi tiap anggota dapat mengungkapkan perasaan mereka, seperti rasa puas atau tidak puas dan pemenuhan sosial kebutuhan mereka; d). Fungsi informasi. Komunikasi menyampaikan informasi dari pimpinan ke bawahan atau sebaliknya. Fungsi ini juga memberi petunjuk, pedoman atau informasi yang diperlukan oleh pimpinan atau bawahan. Komunikasi berfungsi menyampaikan informasi yang berhubungan dengan kepentingan umum dan lingkungan tugas organisasi secara keseluruhan. Komunikasi berfungsi menyampaikan informasi dan pengetahuan terutama yang berhubungan dengan pekerjaan atau pelaksanaan tugas dari seseorang kepada orang lain sehingga pekerjaan dapat dijalankan secara benar dan kerjasama tercipta; e) Fungsi komando. Melalui komunikasi atasan memberi instruksi pelaksanaan tugas-tugas tentang apa yang harus dikerjakan kepada bawahan. Komunikasi mendorong dan mengarahkan pegawai untuk melakukan pekerjaan; f). Fungsi integratif. Melalui komunikasi dapat diintegrasikan pekerjaaan dan unit-unit sehingga antara karyawan dan manajer menunjukkan kepaduan (cohesiveness). Disamping itu komunikasi membantu memelihara hubungan sosial organisasional dan membangun kebersamaan orang-orang yang melakukan kerjasama.

Faktor sikap pelaksana menurut Edward III dalam Tahir (2014) merupakan faktor penting ketiga dalam pendekatan mengenai studi implementasi kebijakan publik. Jika implementasi kebijakan diharapkan berlangsung efektif, para pelaksana kebijakan tidak hanya harus mengetahui apa yang harus dilakukan dan memiliki kapabilitas untuk melaksanakannya tetapi mereka juga harus mempunyai keinginan untuk melaksanakan kebijakan tersebut.

\section{Upaya mengatasi hambatan Sikap pelaksana}

Mengatasi hambatan sikap pelaksana ini Badan Permusyawaratan Desa (BPD) berusaha membuat kebijakan supaya kepala desa tidak menyalurkan bantuan dana pemberdayaan kepada masyarakat. mengatasi hambatan sikap pelaksana yaitu walaupun kepala desa sudah membelanjakan barang tapi oleh BPD tidak diperkenankan untuk disalurkan nanti disalurkan oleh PJS kepala desa. Karena pada saat penulis mengambil data di lapangan adalah saat persiapan untuk pemilihan kepala desa pada periode berikutnya, sehingga untuk penyaluran barang yang dibelanjakan dipending oleh BPD. Tapi dari hasil pengamatan penulis barang yag sudah dibelanjakan oleh kepala desa tetap disalurkan. Meskipun pendekatan sikap dan perilaku pemimpin berguna, banyak teori kepemimpinan tidak menemukan satu daftar sifat atau gaya kepemimpinan tunggal terbaik. Suatu teori kepemimpinan kontigensi terkemuka dikembangkan oleh Fred Fiedler dalam Silalahi (2015 : 335) yang menyatakan bahwa kepemimpinan yang baik tergantung pada kesesuaian antara gaya kepemimpinan dan tuntutan situasional.

Faktor Sikap Pelaksana menurut Edward III dalam Tahir (2014) merupakan faktor penting ketiga dalam pendekatan mengenai studi implementasi kebijakan publik. Jika implementasi kebijakan diharapkan berlangsung efektif, para pelaksana kebijakan tidak hanya harus mengetahui apa yang harus dilakukan dan memiliki kapabilitas untuk melaksanakannya tetapi mereka juga harus mempunyai keinginan untuk melaksanakan kebijakan tersebut.

\section{Kesimpulan}

Dari hasil analisis dan pembahasan dalam pengelolaan dan pemanfaatan Dana Desa di Kecamatan Damau Kabupaten Kepulauan Talaud berdasarkan Peraturan Menteri Dalam Negeri Nomor 113 tahun 2014 tentang Pengelolaan Keuangan Desa disimpulkan bahwa : 1). Proses perencanaan dimulai dari penggalian gagasan lewat musyawarah dusun dan kemudian dilanjutkan ke musyawarah desa yang dihadiri oleh perangkat desa bersama dengan lembaga dan tokoh-tokoh masyarakat yang diundang dalam musyawarah desa tersebut. Awalnya sekretaris desa menyusun rancangan Anggaran Pendapatan dan Belanja Desa (APBDesa) berdasarkan Rencana Kerja Pemerintah Desa (RKP Desa) yang kemudian disampaikan kepada kepala desa dan selanjutnya kepala desa menyampaikan kepada Badan Permusyawarata Desa (BPD) untuk selanjutnya dibahas dalam musyawarah desa.Pada proses pelaksanaannya 4 (empat) desa yaitu Desa Peret, Desa Taduwale, Desa Damau dan Desa Akas Balane sudah melaksanakan sesuai dengan regulasi yang ada, hanya 1 (satu) desa yaitu Desa Damau Bowone yang tidak melaksanakan apa yang dituangkan dalam Permendagri tersebut mulai dari perencanaan sampai dengan pertanggungjawabannya hanya sesuai dengan keinginan kepala desa; 2). Proses pelaksanaan ini sudah dilaksanakan berdasarkan Peraturan Menteri Dalam Negeri Nomor 113 Tahun 2014 
tentang Pengelolaan Keuangan Desa, walaupun masih terdapat hambatan pada 1 (satu) desa yaitu Desa Damau Bowone dimana untuk proses pelaksanannya tidak mengacuh pada regulasi yang ada. Misalnya kepala desa tidak mengangkat PTPKD sebagai tim pengelola kegiatan bahkan sekretaris desa tidak pernah melakukan verifikasi terhadap dokumen-dokumen yang berhubungan dengan kegiatan yang dilaksanakan. 3). Proses penatausahaan untuk Desa Peret, Desa Taduwale dan Desa Damau juga sudah sesuai, hanya Desa Damau Bowone dan Desa Akas Balane yang tidak menetapkan Pelaksana Teknis Pengelolaan Keuangan Desa (PTPKD); 4). Proses pelaporan pengelolaan Dana Desa di Kecamatan Damau sudah sesuai dengan Peraturan Menteri Dalam Negeri Nomor 113 tahun 2014 tentang Pengelolaan Keuangan Desa, namun mengenai pelaporan pengelolaan Dana Desa di semester pertama sering terlambat sampai pada bulan September karena Dana Desa tahap pertama masuk di rekening kas desa sering terlambat sehingga mengakibatkan pelaksanaan kegiatan tertunda dan akhirnya laporannya terlambat; 5). Pada proses pertanggungjawaban bendahara sebagai pelaksana teknis dalam pengelolaan keuangan desa belum mampu membuat SPJ sesuai dengan SISKEUDES;

Walaupun proses pengelolaan dan pemanfaatan Dana Desa di kecamatan Damau sudah sesuai dengan Peraturan Menteri Dalam Negeri Nomor 113 Tahun 2014 tentang Pengelolaan Keuangan Desa, namun masih ditemukan beberapa hambatan yaitu struktur birokrasi, sumber daya, komunikasi dan sikap pelaksana. 1). Hambatan struktur birokrasi dalam pengelolaan Dana Desa di Kecamatan Damau yaitu kegiatan didasarkan pada hak asal usul tapi terhambat dengan regulasi, dalam penentuan prioritas pengelolaan Dana Desa di Kecamatan Damau yang dihasilkan lewat musyawarah desa melalui penggalian gagasan dari dusun, terdapat beberapa program kegiatan yang sangat mendesak terutama di bidang infrastruktur tetapi ketika disesuaikan dengan Peraturan Menteri Desa Pembangunan Daerah Tertinggal Nomor 21 Tahun 2015 tentang Penetapan Prioritas Penggunaan Dana Desa Tahun 2016 tidak sesuai sehingga apa yang menjadi prioritas tidak dilaksanakan. Permendesa ini juga tidak sesuai dengan situasi dan kondisi yang ada di Kecamatan Damau. Dari hasil penelitian juga diperoleh bahwa regulasi sering terlambat sehingga masyarakat sudah melakukan musyawarah terlebih dahulu baru Permendesa muncul sehingga pemerintah desa tidak dapat membuat patokan dalam musyawarah desa karena mengikuti Permendesa; 2). Hambatan sumber daya yaitu sumber daya manusia, sarana prasarana dan keadan letak geografis. Sumber daya manusia berkenan dengan kemampuan bendahara yang tidak bisa mengoperasikan leptop bahkan tidak mengerti sistem SISKEUDES. SDM merupakan elemen penting dan merupakan aset terpenting dari organisasi dibanding dengan elemen lainnya. Manusia dalam organisasi memiliki peran dan fungsi penting bagi terwujudnya tujuan organisasi . Manusia yang membuat sumber-sumber lain dari suatu organisasi bekerja dan membuat organisasi bergerak; 3). Hambatan komunikasi hambatan komunikasi antara kepala desa dengan perangkat dan masyarakat. Dimana ada salah satu kepala desa melaksanakan pengelolaan Dana Desa mulai dari perencanaan sampai ke pertanggungjawaban hanya dibuat sesuai dengan keinginan kepala desa dan tidak memperhatikan aspirasi dari masyarakat; 4). Hambatan sikap pelaksana yang ditemukan pada penelitian yaitu sikap pimpinan dalam hal ini kepala desa yang sering mengambil keputusan sendiri tanpa mengadakan musyawarah dengan masyarakat atau perangkat desa lainnya; 5). Proses pertanggungjawaban mengacuh pada apa yang sudah dibelanjakan. Pada saat mencairkan tahap kedua maka SPJ tahap pertama harus dimasukan terlebih dahulu. Pertanggungjawaban mulai dari pelaksana kegiatan mulai tanggal 10 bulan berjalan harus melaporkan semua kegiatan kepada kepala desa dan semua pembelanjaan yang dibelanjakan pelaksana kegiatan itu berupa Surat Pertanggungjawaban (SPJ).

Saran

Ada beberapa hal yang dapat disarankan dalam pengelolaan dan pemanfaatan Dana Desa di Kecamatan Damau : 1). Petunjuk pelaksanaan pengelolaan Dana Desa yang dituangkan dalam SISKEUDES harus sesuai dengan situasi dan kondisi yang ada di desa, supaya proses perencanaan dalam pengelolaan Dana Desa dapat menjawab kebutuhan dasar prioritas yang ada di desa; 2). Pemerintah Daerah Kabupaten Kepulauan Talaud perlu mengadakan sosialisasi, bimbingan dan pelatihan teknis bagi bendahara tentang SISKEUDES; 3). Pembinaan dan pengawasan dari pemerintah daerah harus lebih efektif agar pengelolaan Dana Desa bisa tepat sasaran.

\section{DAFTAR PUSTAKA}

Arikunto, Suharsimi. (2010). Prosedur Penelitian: Suatu Pendekatan Praktik. Jakarta: Rineka Cipta.

Badan Pengawasan Keuangan dan Pembangunan. Halaman http://www.bpkp.go.id/public/upload/unit panduan pengelolaan keuangan desa. Petunjuk Pelaksanaan Bimbingan Dan Konsultasi Pengelolaan Keuangan Desa. Diunduh pada tanggal 3 Maret 2017.

Badan Pengawasan Keuangan dan Pembangunan. Halaman http://www.bpkp.go.id/konten/1737/WartaPengawasan-BPKP-Situs Resmi BPKP 2017. Diunduh pada tanggal 3 Februari 2017.

Bungin, Burhan. (2015). Penelitian Kualitatif. Jakarta: Prenada Media Group.

Chandoevwit Worawan, Ashakul Bawornpan. (2008). The Impact of the Village Fund on Rural Households. Thailand Development Research Institute. Bangkok 10310 Thailand.

Dani Fakrial T, Suhaimi Edi, Maulana Angga T. (2015). Analisis Implementasi Alokasi Dana Desa Pada Kota Lhoksemawe Tahun 2015. Jurnal Ekonomi Dan Kebijakan Publik. Volume 3 Nomor 1, Mei 2016. ISSN. 2442-7411. 
Direktorat Jendral Perimbangan Keuangan Kementrian Keuangan. 2015. Rincian Dana Desa Tahun Anggaran 2016. Halaman http://www.djpk.kemenkeu.go.id/web/attachment/article/608/DANA DESA2016.pdf. Diunduh pada tanggal 10 Februari 2017.

Direktorat Jenderal Perimbangan Keuangan Kementrian Keuangan. Halaman www.djpk.depkeu.go.id/wp/2016/03/03 Penggunaan Dana Desa Kemendes. Diunduh pada tanggal 10 Februari 2017.

Dura, Justita. (2016). Pengaruh Akuntabilitas Pengelolaan Keuangan Alokasi Dana Desa, Kebijakan Desa Dan Kelembagaan Desa Terhadap Kesejahteraan Masyarakat (Sudi Kasus Pada Desa Gubugklakah Kecamatan Poncokusumo Kabupaten Malang). Jurnal JIBEKA Volume 10 Nomor 1 Agustus 2016:26-32.

Fajri Rahmi, Setyowati Endah, Siswidiyanto. (2013). Akuntabilitas Pemerintah Desa Pada Pengelolaan Alokasi Dana Desa (ADD) (Studi Pada Kantor Desa Ketindan, Kecamatan Lawang, Kabupaten Lawang). Fakultas Ilmu Administrasi Universitas Brawijaya, Malang. Jurnal Adiministrasi Publik (JAP) Vol.3,No.7, Hal 1099-1104.

Halim Abdul, Iqbal Muhammad. (2012). Pengelolaan Keuangan Daerah. Edisi Ketiga. Cetakan Pertama. Yogyakarta : Sekolah Tinggi Ilmu Manajemen YKPN.

Hargono Setiabudi Didiek. (2010). Efektifitas Penyaluran Alokasi Dana Desa Pada Empat Desa di Kabupaten Karangasem Propinsi Bali. Tesis : Fakultas Ekonomi Program Studi Magister Perencanaan dan Kebijakan Publik Universitas Indonesia.

Huri Valentina Risti, Djoko Supatmoko. (2013). Akuntabilitas Pengelolaan Dan Pemanfaatan Alokasi Dana Desa Dalam Proses Pembangunan Di Desa Dasri Kecamatan Tegalsari Kabupaten Banyuwangi Tahun 2013. Jurusan Akuntansi Fakultas Ekonomi Universitas Jember (UNEJ).

Husin, Dasmi. (2015). Flexibility Of Bugdet Accountability Using Flow Modification In The Design Of Village Financial Accounting. Politeknik Negeri Lhoksemawe Aceh. Asia Pasific Fraud Journal. Volume 1, Nomor 1 Edition (January-June 2016). Page 19-35.

Ibrahim, (2015). Metodologi Penelitian Kualitatif : Panduan Penelitian Beserta Contoh Proposal Kualitatif. Bandung : Alfabeta.

Ismail Muhammad, Widagdo Kuncara Ari, Widodo Agus. (2016). Sistem Akuntansi Pengelolaan Dana Desa. Fakultas Ekonomi dan Bisnis Universitas Sebelas Maret. Jurnal Volume XIX Nomor 2 Agustus 2016. ISSN 1979-6471

Junaidi. (2015). Perlakuan Akuntansi Sektor Publik Desa Di Indonesia. Fakultas Ekonomi dan Bisnis Universitas Trunojoyo Madura. Jurnal NeO-Bis Volume 9. Nomor.1. Juni 2015.

Karimah Faizatul, Saleh Choirul, Wanusmawatie Ike. (2013) Pengelolaan Alokasi Dana Desa Dalam Pemberdayaan Masyarakat (Studi Pada Desa Deket Kulon Kecamatan Deket Kabupaten Lamongan). Fakultas Ilmu Administrasi Universitas Brawijaya Malang. Jurnal Administrasi Publik (JAP). Volume 2. Nomor 4. Hal. 597-602.

Kholmi, Masiyah. (2016). Akuntabilitas Pengelolaan Dana Desa Studi Di Desa Kedung Kecamatan Kesamben Kabupaten Jombang. Fakultas Ekonomi dan Bisnis Universitas Muhammadiyah Malang. Jurnal Ekonomika Bisnis.Vol. 07 No. 02 Bulan Juli Tahun 2016 Hal 143-152.p-ISSN : 2088-6845 e-ISSN : 2442-8604.

Kurrohman, Taufik. (2015). Accountability of Planning On Village Fund Allocation In OSING Community in Banyuwangi. University Utara Malaysia. International Conference On Accounting Studies (ICAS) 17-20 August 2015. Johor Baru. Johor, Malaysia.

Lebacqz, Karen. (1986). Teori-teori Keadilan. Penerjemah Yudi Santoso. Bandung : Nusa Media.

Makalalag, Astri . (2017). Akuntabilitas Pengelolaan Dana Desa Di Kecamatan Kotamobagu Selatan Kota Kotamobagu. Tesis : Fakultas Ekonomi Dan Bisnis Universitas Sam Ratulangi. Manado.

Mamelo, Gresly. (2016). Analisis Pelaksanaan Dan Penatausahaan Dana Desa Pada Desa Desa Dalam Wilayah Kecamatan Kotamubagu Timur Kota Kotamubagu. Tesis: Fakultas Ekonomi Dan Bisnis Universitas Sam Ratulangi. Manado.

Mardiasmo. (2002). Akuntansi Sektor Publik. Yokyakarta. Andi

Nafidah Nasihatun Lina, Suryaningtyas Mawar. (2015).Akuntabilitas Pengelolaan Alokasi Dana Desa Dalam Upaya Meningkatkan Pembangunan Dan Pemberdayaan Masyarakat. STIE PGRI Dewantara Jombang. Jurnal BISNIS. Vol. 3, No.1, Juni 2015.

Rasul, Syahrudin. (2003).Pengintengrasian Sistem Akuntabilitas Kinerja Dan Anggaran Dalam Perespektif Undang-Undang Nomor 17 Tahun 2003 Tentang Keuangan Negara. Jakarta PNRI

Republik Indonesia. Undang-Undang Nomor 6 Tahun 2014 tentang Desa. Jakarta. Undang-Undang Nomor 25 Tahun 1999 tentang Perimbangan Keuangan Pemerintah Pusat dan Daerah. Jakarta.

Peraturan Pemerintah Nomor 58 Tahun 2005 tentang Pengelolaan Keuangan Daerah.

Jakarta. 
. Peraturan Pemerintah Nomor 43 Tahun 2014 tentang Peraturan Pelaksanaan UndangUndang Nomor 6 Tahun 2014. Jakarta.

. Peraturan Pemerintah Nomor 22 tentang Perubahan atas Peraturan Pemerintah Nomor

60 Tahun 2014 tentang Dana Desa Yang Bersumber dari Anggaran Pendapatan Dan Belanaja Negara. Jakarta.

. Peraturan Menteri Dalam Negeri Nomor. 113 Tahun 2014 Tentang Pengelolaan Keuangan Desa. Jakarta.

. Peraturan Menteri Dalam Negeri Nomor 13 Tahun 2006 Tentang Permendagri Nomor 21 Tahun 2011 tentang Perubahan Kedua Permendagri Nomor 13 Tahun 2006 tentang Pedoman Pengelolaan Keuangan Daerah. Jakarta.

Peraturan Menteri Keuangan Nomor 49/PMK.07/2016 Tentang Tata Cara Pengalokasian, Penyaluran, Penggunaan, Pemantauan dan Evaluasi Dana Desa. Jakarta.

. Peraturan Menteri Desa, Pembangunan Daerah Tertinggal Dan Transmigrasi Nomor 21 Tahun 2015 Tentang Penetapan Prioritas Penggunaan Dana Desa 2016. Jakarta.

Riyanto, Teguh. (2015). Akuntabilitas Finansial Dalam Pengelolaan Alokasi Dana Desa (ADD) Di Kator Desa Perangat Selatan Kecamatan Marangkayu Kabupaten Kutai Kartanegara. eJurnal Administrasi Negara,2015,3 (1) 119-130. ISSN 2337-7542, ejournal.ip.fisip-unmul.ac.id.

Saputra, I Wayan. (2016). Efektivitas Pengelolaan Alokasi Dana Desa Pada Desa Lembean Kecamatan Kintamani, Kabupaten Bangli Tahun 2009-2014. Fakultas Ekonomi dan Bisnis Univesitas Pendidikan Ganesha Singaraja Indonesia. Jurnal Jurusan Pendidikan Ekonomi (JJPE). Volume:6 Nomor : 1 Tahun 2016.

Satori Djam'an, Komariah Aan (2013). Metodologi Penelitian Kualitatif. Bandung : CV. Alfabeta.

Sedarmayanti Hj. (2007). Good Governnance Kepemerintahan Yang Baik dan Good Coorparate Governance Tata Kelola Perusahaan yang Baik. Bandung : Penerbit Mandar Maju.

Siagian, P. Sondang, (2004). Teori Motivasi Dan Aplikasinya. Jakarta : P.T. Rineka Cipta.

Silalahi, Ulber. (2015). Asas-Asas Manajemen. Bandung : P.T. Refika Aditama

Sisoumang Bounthom, Wangwacharakul Vute, Limsombunchai Visit. (2013). Operation and Management of The Village Development Fund in Champasak Province, LAO PDR. Faculty of Economics, Kasetsart University. Bangkok 10900. Thailand. Kasetsart J. (Soc.Sci) 34 : 335-349 (2013)

Soleh Chabib, Rochmansa Heru. (2014). Pengelolaan Keuangan Desa. Bandung : Fokusmedia.

Sugiyono. (2015). Memahami Penelitian Kualitatif. Bandung : CV. Alfabeta

Sujarweni, Wiratna. (2015). Akuntansi Desa. Yogyakarta : Pustaka Baru Press.

Sukanto, Azwardi. (2014). Efektifitas Alokasi Dana Desa (ADD) dan Kemiskinan di Provinsi Sumatera Selatan. Fakultas Ekonomi Universitas Sriwijaya. Jurnal Ekonomi Pembangunan, Juni 2014 Volume 12, No.1 hal: 29-41. ISSN 1829-5843.

Syamsi, Syahrul. (2014). Partisipasi Masyarakat Dalam Mengontrol Penggunaan Anggaran Dana Desa. Program Studi Ilmu Administrasi Negara. Universitas Tribhuwana Tunggadewi. Jurnal Ilmu Sosial Dan Politik. ISSN.2442-6962. Vol. 3, No.1 (2014).

Tahir, Arifin. (2014). “Kebijakan Publik \& Transparansi Penyelenggaraan Pemerintah Daerah”. Bandung : CV. Alfabeta.

Tanjung, A.H. (2011). Akuntansi Pemerintah Daerah Berbasis Akrual. Pendekatan Teknis Sesuai Peraturan Pemerintah Nomor 71/2010. Bandung: CV. Alfabeta.

Tresiana, Novita. (2016). New Public Service Dan Musrembang Desa. Yogyakarta : Suluh Media.

Ulum, Ihyaul MD. (2004). Akuntansi Sektor Publik Sebuah Pengantar. Malang: Penerbitan Universitas Muhammadiyah Malang.

Winarno, Budi. (2005). Teori Dan Proses Kebijakan Publik. Yogyakarta : Media Pressindo.

Yulihantini Tri Dinna, Wardayati Maria Siti. (2016). Financial Accountability in The Management Of Village Fund Allocation. The International Conference On Business And Accounting Studies. Faculty Of Economics and Business University Of Jember. FAA-09.

Yustisia Visi Tim. (2016). Pedoman Resmi Petunjuk Pelaksanaan Dana Desa. Jakarta: Visimedia

Yusuf Burhanuddin. (2015). Manajemen Sumber Daya Manusia di Lembaga Keuangan Syariah. Jakarta : PT. Raja Grafindo Persada. 